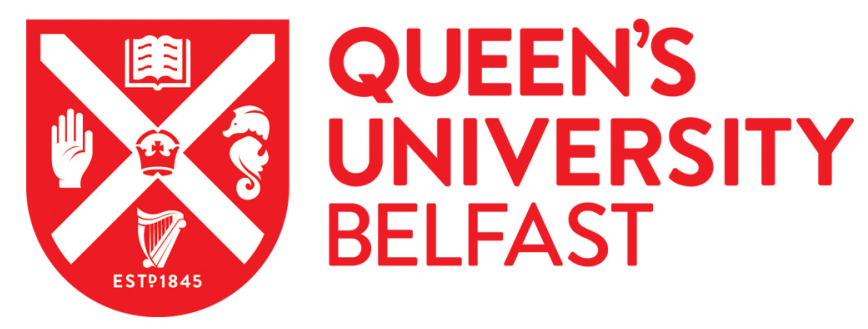

\title{
Review: Mediated pathways, negotiated identities: A critical phenomenological analysis of the lived experience of sexuality in the context of intellectual disability. A commentary.
}

Brown, M., \& Mccann, E. (2017). Review: Mediated pathways, negotiated identities: A critical phenomenological analysis of the lived experience of sexuality in the context of intellectual disability. A commentary. Journal of Research in Nursing, 22(8), 615-617. https://doi.org/10.1177/1744987117735619

Published in:

Journal of Research in Nursing

Document Version:

Peer reviewed version

Queen's University Belfast - Research Portal:

Link to publication record in Queen's University Belfast Research Portal

Publisher rights

Copyright The Author(s) 2017. This work is made available online in accordance with the publisher's policies. Please refer to any applicable terms of use of the publisher.

\section{General rights}

Copyright for the publications made accessible via the Queen's University Belfast Research Portal is retained by the author(s) and / or other copyright owners and it is a condition of accessing these publications that users recognise and abide by the legal requirements associated with these rights.

Take down policy

The Research Portal is Queen's institutional repository that provides access to Queen's research output. Every effort has been made to ensure that content in the Research Portal does not infringe any person's rights, or applicable UK laws. If you discover content in the

Research Portal that you believe breaches copyright or violates any law, please contact openaccess@qub.ac.uk. 


\section{Review: Medicated pathways, negotiated identities: A critical phenomenological analysis of the lived experiences of sexuality in the context of intellectual disability.}

There have been important and necessary developments and changes in relation to the care and support of people with intellectual disabilities in many countries across the world from institutional to community-based models of care (Shakespeare, 2013). These changes are welcome and important by way of seeking to provide socially inclusive, rights based approaches that aim to empower and enable this often-marginalised population (WingesYanez, 2014; World Health Organization, 2015). There is now an increasing focus on relationships and sexuality concerns from the perspective of people with intellectual disabilities that takes account of their individual needs and aspirations (Arias et al., 2009). Sitting alongside their perspectives are the interests and concerns of parents, families and carers (Friedman et al., 2014).

From the research perspective of studies involving the voices of adults with intellectual disabilities, there is the clear articulation of the desire to form and maintain, friendships and in some cases, romantic and intimate relationships (Bernet, 2011; Turner \& Crane, 2016). The existing research literature highlights the tensions that may be evident between the right to autonomy and decision making by adults with intellectual disabilities and the need of parents, families and carers to exercise control over the relationships and expression of sexuality (Yau et al., 2009; Rushbrook et al., 2014). These concerns can be legitimate due to issues related to exploitation and harm, with policy responses aiming to protect those who may be particularly vulnerable (Bane et al., 2012; Schaafsma et al., 2015).

The reviewed study by Pariseau-Lagault and Holmes of the lived experiences of sexuality of people with intellectual disabilities is particularly welcome and adds to a growing and evolving research evidence-base in this area. The paper makes a valuable contribution as it presents the subjective accounts and voices of adults with intellectual disabilities, while also including the views and experiences of parents and support workers. It therefore offers a rounded and wellpresented account of the various perspectives that need to be recognised and considered.

Undertaking research involving people with intellectual disabilities can often be difficult and challenging. This is even more pronounced when researching, what is still considered, a taboo subject such as sexuality (Hall et al., 2010; McCann et al., 2016). To grow the research evidence-base there are many considerations that need to be addressed, including overcoming barriers to identifying and accessing the population, ethical concerns, recruitment and retention, capacity to consent and the ability of some to participate in the research process (Bigby et al. 2014).

The researchers overcame these challenges and adopted an appropriate research design that enabled the voices and experiences of adults with intellectual disabilities to be included. The use of Interpretive Phenomenological Analysis, (IPA), is a relevant research approach as it enables the unique experiences of the individual participants to be expressed and recorded (Brown et al. 2016). IPA as a methodology has the advantage of enabling the researcher to undertake a detailed analysis of the data that allows for a full description of the personal experiences of the participants. It also allows for an interpretation of those experiences by both the researcher and participants within the research process (Smith et al. 2009).

Undertaking research involving people with intellectual disabilities presents additional issues that need to be overcome. Researchers undertaking studies with this population, can therefore 
include details of the obstacles they experience and importantly how they were overcome. Including such reflective accounts have the potential to inform future research approaches and what worked. This is necessary to ensure that the drive towards socially inclusive care and support for people with intellectual disabilities is a reality and the evidence-base in sensitive areas such as sexuality attracts further and wider research attention.

\section{References}

Arias, B., Ovejero, A., \& Morentin, R. (2009). Love and emotional well-being in people with intellectual disabilities. The Spanish Journal of Psychology 12(1), 204-216.

Bane, G., Deely, M., Donohoe, B., Dooher, M., Flaherty, J., Iriarte, E.G., Hopkins, R., Mahon, A., Minogue, G., Donagh, P.M., \& Doherty, S.O. (2012). Relationships of people with learning disabilities in Ireland. British Journal of Learning Disabilities 40(2), 109-122.

Bigby, C., Frawley, P., \& Ramcharan, P. (2014). Conceptualizing inclusive research with people with intellectual disability. Journal of Applied Research in Intellectual Disabilities, 27(1), 3-12.

Brown, M., Chouliara, Z., MacArthur, J., McKechanie, A., Mack, S., Hayes, M., \& Fletcher, J. (2016). The perspectives of stakeholders of intellectual disability liaison nurses: a model of compassionate, person- centred care. Journal of Clinical Nursing 25(7-8), 972-982.

Friedman, C., Arnold, C.K., Owen, A.L. \& Sandman, L. (2014). "Remember our voices are our tools:" Sexual self-advocacy as defined by people with intellectual and developmental disabilities. Sexuality and Disability 32(4), 515-532.

Hall, E. (2010). Spaces of social inclusion and belonging for people with intellectual disabilities. Journal of Intellectual Disability Research 54(Supplement 1), 48-57.

McCann, E., Lee, R. \& Brown, M. (2016). The experiences and support needs of people with intellectual disabilities who identify as LGBT: A review of the literature. Research in Developmental Disabilities 57, 39-53.

Rushbrooke, E., Murray, C., \& Townsend, S. (2014). The experiences of intimate relationships by people with intellectual disabilities: A qualitative study. Journal of Applied Research in Intellectual Disabilities 27(6), 531-541.

Schaafsma, D., Kok, G., Stoffelen, J.M., \& Curfs, L.M. (2015). Identifying effective methods for teaching sex education to individuals with intellectual disabilities: A systematic review. Journal of Sex Research 52(4), 412-432.

Shakespeare, T. (2013). Disability Rights and Wrongs Revisited. London: Routledge.

Smith, J. A., Flowers P. \& Larkin M. (2009) Interpretative Phenomenological Analysis Theory, Methods and Research. London: Sage.

Turner, G.W. \& Crane, B. (2016). Pleasure is paramount: Adults with intellectual disabilities discuss sensuality and intimacy. Sexualities 19(5-6), 677-697. 
Winges-Yanez, N. (2014). Why all the talk about sex? An authoethnography identifying the troubling discourse of sexuality and intellectual disability. Sexuality and Disability 32(1), 107116.

World Health Organization (2015). Sexual Health, Human Rights and the Law. Geneva: World Health Organization.

Yau, M. K. S., Ng, G. S. M., Lau, D. Y. K., Chan, K. S., \& Chan, J. S. K. (2009). Exploring sexuality and sexual concerns of adult persons with intellectual disability in a cultural context. The British Journal of Development Disabilities 55(109), 97-108.

Michael Brown is Professor of Nursing at the School of Nursing and Midwifery, Queen's University Belfast, Northern Ireland and specialises in the care of people with learning disabilities.

Edward McCann is Associate Professor in the School of Nursing and Midwifery at the University of Dublin, Trinity College. He has worked extensively in mental health services and education. 